\title{
Values of Character Education and Internal Conflict of Main Figures in Sinar Novel by Aguk Irawan Mizan as Literature Reading Material
}

\author{
Risma Martalena Tarigan \\ Postgraduate Program, State \\ University of Medan, Medan, \\ Indonesia \\ *rismatarigan11@gmail.com
}

\author{
Biner Ambarita \\ Department of Indonesian Language \\ and Literature Education, State \\ University of Medan, Medan, \\ Indonesia
}

\author{
Khairil Ansari \\ Department of Indonesian Language \\ and Literature Education, State \\ University of Medan, Medan, \\ Indonesia
}

\begin{abstract}
Character is an important element in humans. Humans who have good character, are able to manage the knowledge and conflicts faced based on virtue values. The purpose of this research is analysis description values of character education and internal conflict of main figures in Sinar novel by Aguk Irawan Mizan and usefulness as literary reading material. The method used is descriptive qualitative. The technique of collecting data using scrutinize and record, then analysisd using the Miles and Huberman models. The results from study are 33 description of values of religious, hard work, independence, social care and responsibility. Internal conflict of main figures are 15 described the conflicting system of id, ego and super ego. The results of the study were integrated in the reading material and very good criteria were obtained in the reading material. The conclusion that can be drawn is the description of the value of character education and internal conflict of the main figures is a description of the behavior and psychological drive of the character in shaping personality. Based on this, it is recommended that schools be able to apply literary and non-literary book variations to form characters and support Indonesian language learning.
\end{abstract}

Keywords- character; conflict; education; internal; novel; reading, values

\section{INTRODUCTION}

Literary is a reflection in life because that reflects various conflicts in process of character building. Ambarita states literature can develop emotions, change attitudes, building to characters that can improve personal quality [1]. Every human being must have virtue in himself. it is difficult for adolescents to realize the value of virtue in life. It must be realized that when the level of civilization reaches progress, the character of adolescents who have not been solidly based on virtue will be very vulnerable to negative behavior. Based on preliminary observations, phenomena often done by students in schools are cheating, skipping school, speaking harshly, committing acts of violence both physically and psychologically (ridicule and discrimination) as well as behaviors that trigger a commotion in the learning process. This is supported by Jokebet Saludung's research stating that character education has not been maximally approved and still uses conventional methods [2].

Character is not only issue in the world of education. Internal conflict in the lives of adolescents is also rife now. Rensh, et al in their research stated that virtue values were transmitted into significant characters through various activities. The application of these values is the result of internal conflict [3].

Sinar by Aguk Irawan Mizan's novel is a psychological novel that illustrates the value of strong character education and good handling of internal conflicts. This novel illustrates the internal opposition of main figures to finally form a character. Through literary works in the form of novels, readers get the teaching of values. The results of the analysis in this novel will be integrated into reading the material in the form of enrichment books.

\section{LITERATURE REVIEW}

\section{Values of Character Education}

Identity is an absolute thing that must be owned by the next generation. Socrates revealed "Know yourself" which means having an identity that becomes an identity as a human being and a nation. That put forward by Socrates implies the meaning that the greatest enemy to humans is himself. However, if the human being can recognize his characteristics, then in any situation his actions are controlled. Lickona in Saptono states that a person is said to have good character when in real life every day has three habits, namely: thinking about good things, wanting good things and doing good things [4]. This means that in the process of inculcating the value of character education, it is not only limited to the introduction of the value of character education but its habituation in daily life. Lickona in Samani, et al revealed that the process of internalizing the value of character education towards noble morals in each student, there are stages of strategy that must be passed as in the following picture [5]. 


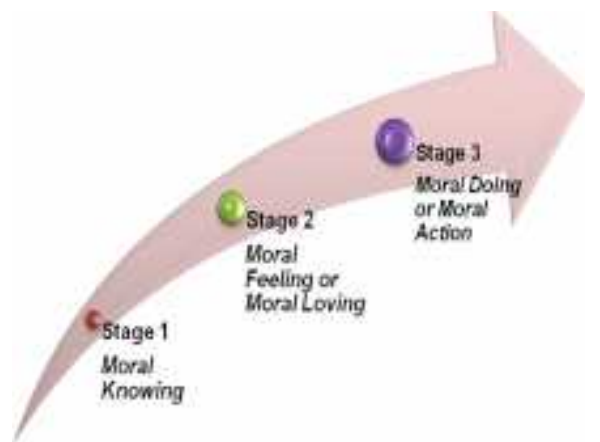

Fig. 1. Stages Of Internalization Character Education Values

These three stages are dynamic processes. The peak of the internalization stage of the value of character education will form a strong and quality person so that in any condition and conflict, the individual will not be easily influenced by negative things. National Education of Ministry suggested 18 values of character education. The following is the value of character education which is limited to religious values, hard work, independence, responsibility, and social care[6].

TABLE 1. INDICATOR OF CHARACTER EDUCATION VALUES

\begin{tabular}{|c|c|c|c|}
\hline & Values & Description & Indicator \\
\hline 1. & Religious & $\begin{array}{l}\text { Obedient attitudes } \\
\text { and behaviors in } \\
\text { implementing } \\
\text { religious teachings, } \\
\text { being tolerant of the } \\
\text { implementation of } \\
\text { other religious } \\
\text { worship, and living } \\
\text { in harmony with } \\
\text { followers of other } \\
\text { religions. }\end{array}$ & $\begin{array}{l}\text { 1. Pray before } \\
\text { and after the } \\
\text { lesson. } \\
\text { 2. Allow } \\
\text { carrying out } \\
\text { worship. } \\
\text { 3. Give a } \\
\text { smile, } \\
\text { greetings, and } \\
\text { polite }\end{array}$ \\
\hline 2. & Hard work & $\begin{array}{l}\text { Behavior that shows } \\
\text { earnest effort in } \\
\text { overcoming various } \\
\text { learning barriers, } \\
\text { assignments and } \\
\text { completing tasks as } \\
\text { well as possible. }\end{array}$ & $\begin{array}{l}\text { 1. Create a } \\
\text { healthy } \\
\text { competition } \\
\text { atmosphere } 2 \text {. } \\
\text { Try your best } \\
\text { to get the best } \\
\text { results }\end{array}$ \\
\hline 3. & Independent & $\begin{array}{l}\text { Attitudes and } \\
\text { behaviors that are } \\
\text { not easy depend on } \\
\text { others in } \\
\text { completing tasks. }\end{array}$ & $\begin{array}{l}\text { 1. Not } \\
\text { dependent on } \\
\text { others } \\
\text { 2. Carry out } \\
\text { activities } \\
\text { based on their } \\
\text { abilities }\end{array}$ \\
\hline 4. & Responsible & $\begin{array}{l}\text { The attitude and } \\
\text { behavior of a person } \\
\text { to carry out their } \\
\text { duties and } \\
\text { obligations, which } \\
\text { he should do to } \\
\text { oneself, society, the } \\
\text { environment }\end{array}$ & $\begin{array}{l}\text { 1. Carry out } \\
\text { tasks well and } \\
\text { on time } \\
2 . \text { Willing to } \\
\text { apologize if } \\
\text { guilty and try } \\
\text { not to repeat } \\
\text { again }\end{array}$ \\
\hline
\end{tabular}

\begin{tabular}{|l|l|l|l|}
\hline & $\begin{array}{l}\text { (natural, social and } \\
\text { cultural), country } \\
\text { and God. }\end{array}$ & $\begin{array}{l}\text { 3. Dare to bare } \\
\text { the risk or } \\
\text { consequences } \\
\text { of all his } \\
\text { actions }\end{array}$ \\
\hline 5. & Social care & $\begin{array}{l}\text { Attitudes and } \\
\text { actions that always } \\
\text { want to assist other } \\
\text { people and } \\
\text { communities in and in } \\
\text { need. }\end{array}$ & $\begin{array}{l}\text { 1. Emathize } \\
\text { others } \\
\text { 2. Perform } \\
\text { social action } \\
\text { 3. Building } \\
\text { harmony of } \\
\text { class citizens }\end{array}$ \\
\hline
\end{tabular}

\section{Internal Conflict of Main Figures in Novel}

Conflict means a problem. Meredith and Fitzgerald in Nurgiyantoro stated that conflict leads to the understanding of something unpleasant that occurs and is experienced by characters who if the character has the freedom to choose, he (they) will not choose the event happened to him [7]

The importance of the presence of conflict in a story is explained by Stanton that the two basic elements that construct the flow are conflict and climax [8]. Without conflict in a plot, the contents of the story in the work of fiction will not be interesting because there is no climax process which according to Tarigan is the highest peak in a series of peaks where the forces in conflict reach the highest intensification[9]. Nurgiyantoro explains that "Internal conflict (psychiatric conflict, inner conflict) is a conflict that occurs in the heart and mind, in the soul of a character (or figuress) story. So, internal conflict is a conflict experienced by humans with themselves "[10]

\section{Sigmund Freud's Theory}

Freud stated that human behavior is a product of the interaction of the three systems, namely: id, ego, and super ego. That is, that every behavior contains an element of lust (impulse), an element of real awareness and an element of control, regardless of right or wrong and good or bad.

According to Hall and Lindzey stated the three systems that make up human personality (id, ego, and super ego) have different functions, properties, components, working principles, dynamism, and mechanisms [11]. However, the id, the ego, and the super ego interact so closely with each other that it is difficult (impossible) to separate their effects and assess their relative contribution to human behavior. Id is a system based on the pleasure principle, which is: trying to get pleasure (comfort) and avoid pain. The ego is a personality system that acts as an individual director to the world of objects from reality. Super ego is like conscience that recognizes good and bad values. Super ego is the moral and ethical power of personality, which operates using an idealistic principle. 


\section{RESEARCH METHOD}

Type of research is qualitative with descriptive methods. The research procedures carried out are (1) Formulation of ideas and research focus, (2) Adjustment of the research paradigm with selected substantive theories. (3) Formulation of research design that discusses three designs, breakdown and breakdown of results, (4) Overall data collection, (5) Data analysis, (6) Dissemination of findings by integrating findings as literary reading material in high school. The technique of collecting data is by scrutinizing and record. In this study, use the human instrument. Researchers analyzed the value of character education with the provisions of the Ministry of National Education about the value of character education. Inner conflict in the main character of the novel will be analyzed by Sigmund Freud's theory. Then the entire data was analyzed by using Miles and Huberman's model analysis techniques.

\section{RESULT AND DISCUSSION}

\section{Values of Character Education}

Based on research that has been done, the value of character education contained in Sinar by Aguk Irawan Mizan's novel totaling 33 data. The value of character education will be detailed in the table below.

TABLE 2. RESULT OF ANALYSIS CHARACTER EDUCATION VALUES

\begin{tabular}{|c|c|c|}
\hline & $\begin{array}{c}\text { Values of Character } \\
\text { Education }\end{array}$ & Amount of Data \\
\hline 1. & Religious & 5 data \\
\hline 2. & Hard Work & 4 data \\
\hline 3. & Independent & 12 data \\
\hline 4. & Responsible & 8 data \\
\hline 5. & Social care & 4 data \\
\hline & Total & 33 data \\
\hline
\end{tabular}

\section{A. The Value of Character Education Reflects Human Relations with God}

\section{a. Religious Values}

Religious values are the most essential values because they originate from human belief in their Lord. Human trust in God is reflected through attitudes and thoughts that lead to spirituality. Three indicators are covering the implementation of religious values, namely: (1) Praying before and after the lesson, (2) Providing opportunities to practice worship, and (3) Giving a smile, greeting, greetings, courtesy, and courtesy. These indicators serve as benchmarks in the analysis of religious values in Sinar by Aguk Irawan Mizan's novel. Sinar's attitude is a reflection of her religious attitude towards her mother. Sinar's attitude fulfills the second indicator of religious value, which allows practicing worship and can be seen from the following quotation.

The affection that Sinar pours out completely. This little girl is probably far more mature than his new age of four years. Several times he shifted his mother's body as much as he wanted to do. Just at the evening prayer, he took the ablution water for his mother, as if there was no fatigue. After his mother prayed and released his face, his mother was bribed with an abundant outpouring of hearts.

\section{B. The Value of Character Education that Reflects Human Relations with Himself}

\section{a. Hard Work Values}

Hard work is a way to achieve both the desired and necessary goals in life. Achieving goals is not done by waiting and asking, but there is an effort to fight for something you want to achieve. Indicators that illustrate the value of hard work are: (1) Creating a healthy competition atmosphere and (2) Trying your best to get the best results. These two indicators will serve as benchmarks for analyzing the value of hard work in this study. This can be seen in the following quotation.

And when the sun has swollen that piece, as usually, she went to the corner of the yard, under a palm tree not far from her stage house. There she to study. No friends, also the kind of person who guides her. Her sister, only accompanied occasionally when he was home.

\section{b. Independent Values}

Mandiri is an effort to rely on yourself as a whole. The attitude of independence has several indicators as benchmarks to analysis it, namely: (1) Not dependent on others and (2) Carrying out activities based on one's abilities. The following is a quote that illustrates the independence of Murni and Risa.

\begin{abstract}
"Have you started begging?"
"No ma, no. I get rice from people who want to exchange for my wood branches"

Then Murni is silent and no longer suspects her child. Hearing this answer, Murni was relieved, because what she was worried about did not happen. The concern is that the child is now a beggar, and it is a taboo for him, because according to him under any circumstances, people should not be able to beg because the beggar's mentality can damage the child's future. In addition, he also believes that sustenance will come if someone wants to try, yes Murni always slips the belief in Risa, that the little ant can still eat because he tries, after all, if you want to beg isn't it better to beg directly to the Creator Almighty Rich and have given many gifts to humans, rather than begging to others who must have many shortcomings.
\end{abstract}

\section{c. Responsible Values}

Responsibility is the human consciousness in carrying out obligations and accepting risks for the actions carried out. Indicators that serve as benchmarks for the value of responsibility are: (1) Carry out tasks properly and on time, (2) Willing to apologize if guilty and try not to repeat and (3) Dare to bear the risk or consequences of all his actions. The 
following is a quote that illustrates the attitude of responsibility undertaken by Sinar.

Today it is still completely new, about half of the compilation of city people still snoring and climbing on their blankets. That's huge, old, old. Therefore, the light starts from what is determined, such as starting to defecate, perform ablution and pray or something else. After that, he prepared a stove to cook rice, wash kitchen utensils and wash his clothes and clothes.

\section{The Value of Character Education that Reflects Human Relations with the Community \\ a. Social Care}

The value of social care is a reflection of the attitude that always wants to assist people who need help. Indicators in the value of social care are: (1) Empathize to others (2) Perform social action (3) Build harmony among class members. Here is a description of the value of social care and meeting the first indicator.

Hardi, the boy whose house is closest to Sinar, when he comes home from school often helps Sinar to collect dry logs that have broken from his tree trunks and are lying on fields or roadside.

\section{Internal Conflicts of Main Figures}

Sigmund Freud formulated the theory of psychoanalysis by detailing the human personality system consisting of id, ego, and super ego. Internal conflict occurs because of a conflict between the three personality systems. Based on the research that has been done, the inner conflicts experienced by the main character in the novel Agaman Irawan Mizan's Sinar will be presented in the table below.

\begin{tabular}{|c|c|c|c|c|}
\hline \multirow[b]{2}{*}{$\begin{array}{c}\text { Main } \\
\text { Figures }\end{array}$} & \multicolumn{3}{|c|}{ Internal Conflict } & \multirow[b]{2}{*}{$\begin{array}{l}\text { Amount } \\
\text { of Data }\end{array}$} \\
\hline & Id & Ego & $\begin{array}{c}\text { Super } \\
\text { ego }\end{array}$ & \\
\hline Murni & 6 data & 6 data & 6 data & 18 data \\
\hline Sinar & 9 data & 9 data & 9 data & 27 data \\
\hline Total & 15 data & 15 data & 15 data & 45 data \\
\hline \multicolumn{4}{|c|}{ Internal Conflict } & 15 data \\
\hline
\end{tabular}

Sinar solves internal conflicts that eventually build a strong character in her. The following is an excerpt of the internal conflict experienced by Sinar.

(Id) At the same time, Sinar wanted to change into a uniform quickly and leave her mother for school.

(Ego) But his little heart still objected to leaving his mother alone in pain like this. Especially when he imagined his mother sober up like that.

(Super Ego) No, mom. I can't go to school if my sister not arrive

Freud's theory lays the foundation that every human being has desires, needs, and comfort. Sinar wants to go to school but the ego system gives direction that in reality, she can't go because her mother is sick. The inner conflict is resolved by the role of the super ego in bringing up value for making decisions.

\section{Results of the Study as Reading Material}

The reading material in the form of enrichment books is a product from this research. The results of the study of the value of character education and the internal conflicts of the main figures in Sinar by Aguk Irawan Mizan's novel are integrating into this enrichment book. Then the book is tried to students and find out the benefits of the enrichment book. Based on the results of interviews with three Indonesian language teachers in 4 Binjai Senior High School it was concluded that the enrichment book was appropriately used as a companion textbook because it contained complete knowledge and could shape the character of students. This enrichment book is also by following the characteristics of students in high school. Meanwhile, based on a questionnaire given to 32 students the conclusion was that the students' responses to the enrichment book were $82.2 \%$ with very good criteria.

\section{CONCLUSION}

Conclusions lead to the essence of the answer to the problem formulation. Based on the results and discussion of the study, the conclusions obtained are as follows.

1. There are 33 values of character education in the Sinar by Aguk Irawan Mizan's novel namely: 5 religious values, 4 values of hard work, 12 values of independent, 4 values of social care and 8 values of responsibility. The values of character education are life representations reflected in literary works in the form of novels.

2. There are 15 internal conflicts between the main figuress in Sinar by Aguk Irawan Mizan's novel. The main figuress in the novel are Murni and Sinar. The internal contradictions of the Murni and Sinar figuress are analyzed based on aspects of id, ego and super ego in the human personality system revealed by Sigmund Freud.

3. The results of the study of the Sinar by Aguk Irawan Mizan's novel are integrated into reading the material in the form of enrichment books. The enrichment book tested received good responses from teachers and high school students. Reading material based on the results of a proper and appropriate novel study is used as a companion textbook.

\section{REFERENCES}

[1] B. Ambarita, 2010, "Various Approaches in Teaching Indonesian Language and Literature" Alfabeta, Bandung, pp. 119.

[2] J. Saludung, 2014 "Analysis of Evaluation Results of the Nation Character Education Program. In Badrun (Eds.), The Role of Education in Nation Character Building" Indo Media Pustaka, Yogyakarta, pp8295

[3] Rensh, et al, 2016, "Research into the Specific Aspects of Internal Conflict Displays in the Course of Professional Identification" International Journal of Environmental \& Science Education, pp. 7087

[4] Saptono, 2011, "Dimensions of Character Education" The essence of Erlangga Group, Salatiga, pp. 20. 
[5] Muchlas Samani and Hariyanto, 2011, "Concepts and Models of Character Education" PT Youth rosda works, Bandung, pp. 50.

[6] National Education of Ministry, 2010, "Development of Nation Cultural and Character Education" National Education of Ministry, pp.9-10.

[7] B. Nurgiyantoro, 1995. "Theory of Fiction Studies" Gadjah Mada University Press, Yogyakarta, pp.122

[8] R. Stanton, 2007 "Theory of Fiction” Student Library, yYogyakarta, pp. 31.
[9] H. Tarigan, 1984 "Basic Principles of Literature" Angkasa, Bandung. pp. 128 .

[10] B. Nurgiyantoro, 2013, "Theory of Fiction Study" Gajah Mada University, Yogyakarta, pp.181.

[11] Hall, S. Calvin and Gardner Lindzey, 1993, "Psychodynamic Theories (Clinical)" Indonesian translation by Dr. A. Supratiknya, Canisius, Yogyakarta, pp. 63-64. 